\title{
Crítica de arte no primeiro romantismo alemão e produção de subjetividade
}

\author{
Art criticism in the early German Romanticism \\ and the production of subjectivity
}

\section{Alexandre Pieroni Calado}

Alexandre Pieroni Calado

Diretor de teatro, é membro do Centro de Investigação

em Artes e Comunicações (UAlg/IPLisboa).

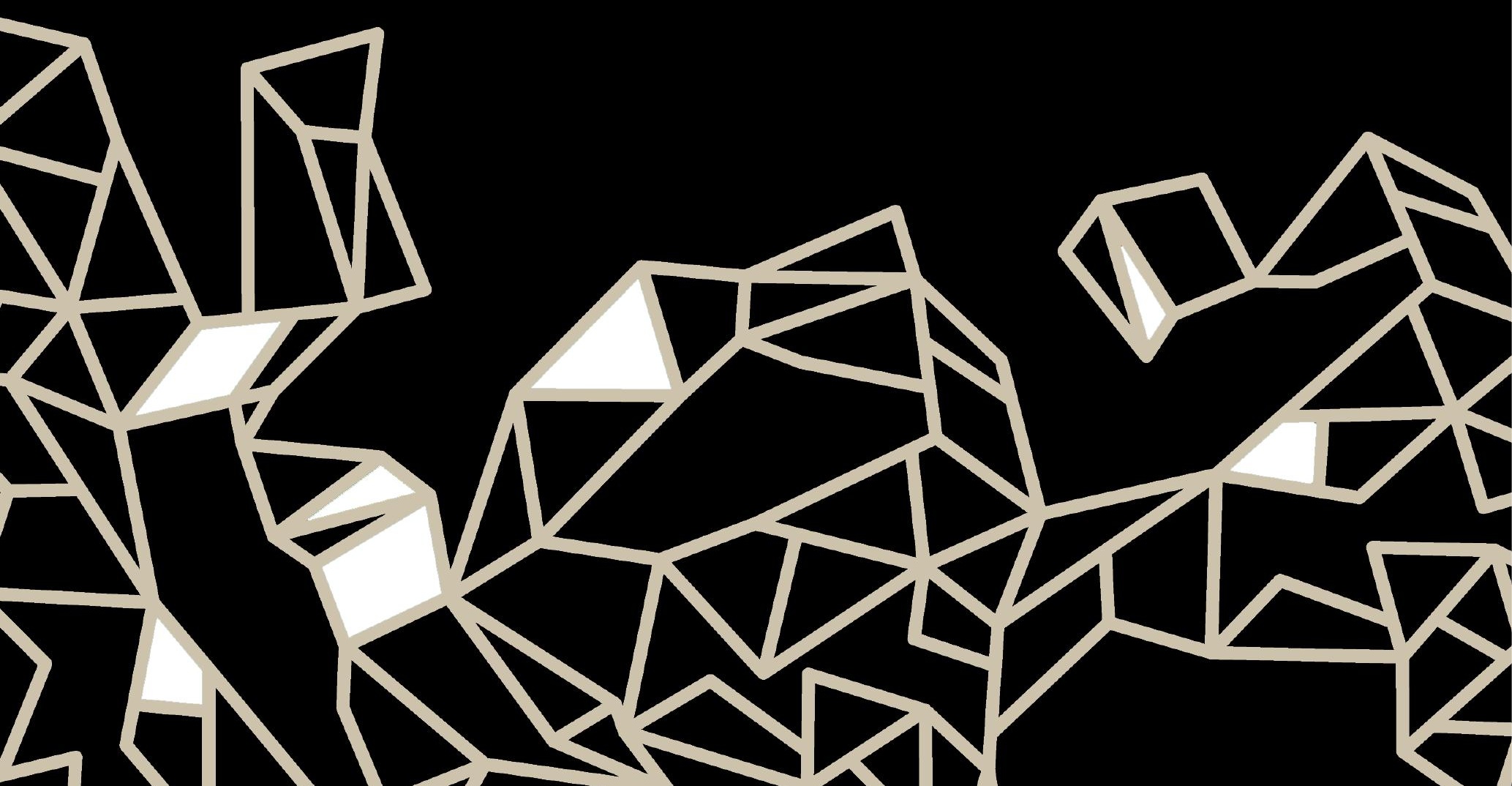




\section{Resumo}

Neste texto sustento que certa noção de crítica de arte proposta por Friedrich Schlegel e pelos primeiros românticos alemães merece uma oportuna retomada, tendo em vista o problema da produção de subjetividade. Começo por delinear a concepção de crítica de Schlegel, tal como é discutida por Walter Benjamin em O Conceito de Crítica de Arte no Romantismo Alemão (1920). Neste movimento expositivo destaco três aspectos da referida noção de crítica: o caráter imanente dos critérios de apreciação do trabalho artístico; a dimensão de preparação do núcleo prosaico da obra; e o sentido positivo, criativo e de restituição da obra individual à infinitude da arte do gesto crítico. Concluo procurando articular a noção de crítica com a noção de "simpoesia", presente na reflexão de Schlegel e de outros primeiros românticos, sustentando que essas noções podem contribuir para um vocabulário e um discurso de resistência no quadro da produção massiva de subjetivação e de dessubjetivação contemporâneas.

Palavras-chave: Crítica de arte, Friedrich Schlegel, Primeiro Romantismo alemão, Produção de subjetividade.

\section{Abstract}

In this text I argue that a certain concept of criticism fostered by Friedrich Schlegel and the early German romantics is worth recovering for a consideration of the problem of subjectivity. I start by outlining the concept of criticism by Schlegel as it is presented by Walter Benjamin in his The Concept of Art Criticism in German Romanticism (1920). Here I stress three aspects of the abovementioned concept: the immanent dimension of the art work's judgement criteria; the preparation of the prosaic nucleus of the art work; and the critical gesture as positive, creative, and as a restitution of the individual work to the infinitude of art. I conclude by articulating this notion of criticism with the idea of "sympoetry" proposed by Schlegel and other early romantics, sustaining that these notions can contribute to a resistance vocabulary and discourse in the context of contemporary subjectivity mass production.

Keywords: Art criticism, Friedrich Schlegel, Early German Romanticism, Subjectivity production. 


\section{A noção de crítica de arte em Friedrich Schlegel e nos primeiros românticos}

The task for the criticism of art is knowledge in the medium of reflection that is art.

(BENJAMIN, 2002, p. 151)

Numa época marcada pela absoluta expansão dos territórios artísticos e pela ampla diversidade de correntes estéticas, em que os artistas são chamados a revelar mais e mais competências discursivas sobre o próprio trabalho e em que a crítica profissional vem sendo paulatinamente segregada do espaço público, a recuperação do discurso empreendido pelos primeiros românticos alemães [Frühromantik] e por Friederich Schlegel (1772-1829), em particular, assume total pertinência. Poeta, investigador, docente e crítico literário, Friedrich Schlegel tem sido reconhecido como um dos precursores da ideia moderna de crítica, e o seu pensamento é tido por Walter Benjamin como verdadeiramente exemplar para uma compreensão da noção de crítica no Primeiro Romantismo (BENJAMIN, 2002, p. 118). Importa desde já deixar claro que para Schlegel o termo "crítica" [Kritik] se refere à crítica de arte, e que por "arte" entende a literatura, em especial. Apesar disso, trata-se de um conceito cuja plasticidade e amplitude excedem largamente as fronteiras disciplinares, revelando-se de grande utilidade no vasto campo das práticas artísticas em geral. ${ }^{1}$ Farei a exposição do conceito de crítica desenvolvido por Schlegel acompanhando de perto Walter Benjamin (2002), em O Conceito de Crítica de Arte no Romantismo Alemão, pelo que farei um percurso rápido pelos contornos da teoria do conhecimento de Schlegel e dos primeiros românticos, de forma a permitir, em seguida, uma aproximação à teoria do conhecimento da arte, na qual se imbrica, finalmente, a noção de crítica de arte.

1 Neste estudo será especialmente tido em consideração o pensamento desse autor relativo ao período sensivelmente entre 1795 e 1804, em que publicou nas revistas Athenaeum e Lyceums o seu Ideen, bem como textos críticos sobre Gotthold Ephraim Lessing (17291781) e Johann Wolfgang von Goethe (1749-1832), entre outros. Nesse período esteve Schlegel próximo do grupo de Jena, no qual desempenharam também importante papel autores como o seu irmão August Wilhelm von Schlegel (1767-1845), além de Friedrich Daniel Ernst Schleiermacher (1768-1834), Ludwig Tieck (1773-1853), Georg Philipp Friedrich von Hardenberg (Novalis) (1772-1801), entre outros autores frequentemente integrados no Primeiro Romantismo. 


\title{
O conhecimento da Natureza: reflexão, meio de reflexão, experiência
}

\author{
Man is Nature creatively looking back at itself.
}

(SCHLEGEL, 1991, p. 96)

Para uma aproximação à teoria do conhecimento da natureza que subjaz à teoria do conhecimento da arte de Friedrich Schlegel e dos primeiros românticos, seguindo os passos de Walter Benjamin, importa começar por circunscrever o sentido dos termos "reflexão", "meio de reflexão" e "experiência". Para uma compreensão do papel da noção de "reflexão" na teoria do conhecimento dos primeiros românticos, é incontornável a evocação do pensamento do filósofo Johann Gottlieb Fichte $(1762-1814)^{2}$ e, com efeito, encontramos Fichte como alvo da dedicatória que Friedrich Schlegel elaborou para o seu Os pensamentos e opiniões de Lessing (1804). Fichte, especialmente em Wissenschaftslehre (1794-1795), dá uma definição de "reflexão" que se aproxima dessa breve passagem do poeta: "[The] action of freedom, through which the form turns into the form of the form as its content and returns into itself, is called 'reflection'”(FICHTE apud BENJAMIN, 2002, p. 122). Pode ler-se nessas palavras a assumpção de que o pensamento tem uma forma e não apenas um conteúdo; correlativamente, uma teoria que procure compreender a acção da inteligência deverá ter em conta que essa acção é formalmente anterior a qualquer coisa objectiva sobre a qual venha a operar. A noção de reflexão avançada por Fichte e apropriada pelos primeiros românticos refere-se, nas palavras de Benjamin, a uma relação que o pensamento tem consigo-mesmo, sendo, portanto, a relação que está mais próxima do pensamento em geral e aquela a partir da qual todas as outras se desenvolvem (BENJAMIN, 2002,

2 Um dos fundadores do idealismo alemão, Fichte desenvolveu o seu trabalho a partir da filosofia de Immanuel Kant (1724-1804), tendo se dedicado a problemas como a natureza da consciência, entendida como autoconsciência ou consciência de si-mesmo. As ideias de Fichte apresentadas nas múltiplas reedições das Lições sobre a Vocação do Sábio, como as da crença na absoluta liberdade e independência do espírito humano e a crença na vocação humana para a unidade, identidade e consonância consigo mesmo, exerceram uma enorme influência sobre toda uma geração, repercutindo em diversas áreas do pensamento. A propósito desse entendimento fichteano da subjetividade humana como atravessada por uma permanente busca pela completude e da crítica como uma atividade que concorre para o contínuo aperfeiçoamento humano, Constantino de Medeiros utiliza a expressão "ânsia de infinito" [Sehnsucht nach Unendlichen] (DE MEDEIROS, 2015, p. 98102). Schlegel escreve, a propósito da importância desse pensador para si e sua época, no Fragmento 216 da Revista Athenaeum: "The French Revolution, Fichte's philosophy, and Goethe's Meister are the greatest tendencies of the age" (SCHLEGEL, 1991, p. 46). 
p. 121). Numa formulação simples, encontramos os ecos dessas ideias nas palavras de Schlegel, quando escreve: "Feeling that is aware of itself becomes spirit” (SCHLEGEL, 1991, p. 69).

Entendendo que a reflexão enquanto dobra do pensamento sobre ele-mesmo constitui o germe de todo o conhecimento da natureza, cumpre sublinhar que essa intuição se associa à noção de que qualquer conhecimento é, em última instância, conhecimento de si-mesmo. Note-se de passagem, como faz desenvolvidamente Walter Benjamin no texto que temos vindo a acompanhar, que os primeiros românticos consideram como verdadeira a intuição metafísica que tudo o que é real é uma entidade dotada de espírito, pensante um axioma cuja fundamentação e consequências ultrapassam o âmbito deste texto, mas necessário para estabelecer a ideia de que todo o real se apresenta como um "meio de reflexão". Essa intuição pode ser entendida como um novo eco da filosofia de Fichte, que havia questionado a distinção proposta por Kant entre noumena e phenomena, defendendo antes que a consciência não está fundada em o que quer que seja fora dela; nestes termos, o conhecimento produzido por um sujeito será sempre conhecimento do processo de autoconhecimento de um objeto. Em rigor, essa teoria implica que a dicotomia sujeito/objeto carece de sentido, como o expõe de forma clara Benjamin:

What approach does the investigator have to adopt in order to achieve knowledge of nature, assuming that the real is a medium of reflection? $\mathrm{He}$ will understand that no knowledge is possible without the self-knowledge of what is to be known, and that this can be called into wakefulness by one center of reflection (the observer) in another (the thing) only insofar as the first, through repeated reflections, intensifies itself to the point of encompassing the second. (BENJAMIN, 2002, p. 147-148)

Parafraseando, pode-se dizer que o conhecimento se estabelece por uma sorte de empatia que se gera entre o observador e a coisa, através da qual o primeiro vem a partilhar o autoconhecimento que o segundo tem de si-mesmo. Assim sendo, o objeto da natureza se torna conhecido do observador na medida em que este consegue abarcar o processo de reflexão próprio do objeto, tornando-o um aspecto da própria reflexão enquanto sujeito. Segundo essa perspectiva, portanto, a natureza se oferece enquanto "meio de reflexão" na medida em que possibilita, em maior ou menor grau consoante o objeto, 
uma reflexão repetida que intensifica o sujeito, ampliando a sua capacidade de conhecer. Na medida em que há, via esse processo de intensificação, uma constituição simultânea do conhecimento do que é conhecido e do que conhece, é possível entender que a observação é, menos que um procedimento distanciado, uma verdadeira forma de "experiência" que observador e coisa partilham. Para elucidar este aspecto da produção do conhecimento segundo o pensamento dos primeiros românticos, Benjamin utiliza termos como "observação irônica" e "observação mágica", porquanto estes aludem à dimensão intuitiva que atravessa o próprio processo de conhecer, e cita Novalis, que expressamente utiliza o termo "experiência" para a ele se referir:

\footnotetext{
The process of observation is at the same time a subjective and objective process, an ideal and a real experiment. Proposition and product must be accomplished simultaneously if the process is to be perfectly achieved. If the object observed is already a thesis, and the process thoroughly absorbed in thought, then the result will be the very same thesis, only at a higher level. (NOVALIS apud BENJAMIN, 2002, p. 148)
}

De forma sumária, introduzi acima as noções de "reflexão," "meio de reflexão" e "experiência" enquanto aspectos centrais da teoria do conhecimento da natureza dos primeiros românticos. Procurando uma síntese possível, pode-se dizer, então, que essa teoria assume que qualquer conhecimento tem por base um processo de reflexão, através do qual um centro de reflexão abarca o processo de reflexão de outro, no âmbito do que é mais bem entendido como uma experiência. Este excurso ser-nos-á bastante útil para compreendermos a teoria do conhecimento da arte de Friedrich Schlegel e dos primeiros românticos, segundo a formulação apresentada por Walter Benjamin.

\section{O conhecimento da arte: julgamento, caracterização, criação de segunda ordem}

Art is a determination of the medium of reflection - probably the most fruitful one that it has received. Criticism of art is knowledge of the object in this medium of reflection. (BENJAMIN, 2002, p. 149)

Procurei na secção anterior apresentar de forma sumária a ideia de que, para os primeiros românticos e Friederich Schlegel, em particular, o conhecimento da natureza se produz por uma reflexão levada a cabo com os meios 
de reflexão que são os objetos da natureza, através de um processo que é mais bem entendido como experiência que como observação. Nesta secção, continuando a seguir o argumento de Walter Benjamin em O Conceito de Crítica de Arte no Romantismo Alemão, busco apresentar a ideia de que para Schlegel a crítica da arte se afigura como conhecimento com o meio de reflexão que é a obra de arte. Essa ideia levar-nos-á a discutir as noções de "julgamento" em arte e do trabalho da crítica enquanto "caracterização" e "criação de segunda ordem".

Se na visão metafísica dos primeiros românticos tudo o que é real constitui um meio de reflexão, a arte se revela, por seu lado, como um meio particular e especialmente fértil. É justamente essa noção que encontramos em Friedrich Schlegel, no Fragmento 116 da Revista Athenaeum, em que escreve:

[a poesia Romântica pode], more than any other form - hover at the midpoint between the portrayed and the portrayer, free of all real and ideal self-interest, on the wings of poetic reflection, and can raise that reflection again and again to a higher power, can multiply it in an endless succession of mirrors. (SCHLEGEL, 1991, p. 32) 3

3 Trata-se de um fragmento algo longo, mas decisivo para compreender o programa estético da literatura dos primeiros românticos e que pode contribuir para uma melhor compreensão dos argumentos aqui desenvolvidos sobre a crítica: "Romantic poetry is a progressive, universal poetry. Its aim isn't merely to reunite all the separate species of poetry and put poetry in touch with philosophy and rhetoric. It tries to and should mix and fuse poetry and prose, inspiration and criticism, the poetry of art and the poetry of nature; and make poetry lively and sociable, and life and society poetical; poeticize wit and fill and saturate the forms of art with every kind of good, solid matter for instruction, and animate them with the pulsations of humor. It embraces everything that is purely poetic, from the greatest systems of art, containing within themselves still further systems, to the sigh, the kiss that the poetizing child breathes forth in artless song. It can so lose itself in what it describes that one might believe it exists only to characterize poetical individuals of all sorts; and yet there still is no form so fit for expressing the entire spirit of an author: so that many artists who started out to write only a novel ended up by providing us with a portrait of themselves. It alone can become, like the epic, a mirror of the whole circumambient world, an image of the age. And it can also - more than any other form - hover at the midpoint between the portrayed and the portrayer, free of all real and ideal self-interest, on the wings of poetic reflection, and can raise that reflection again and again to a higher power, can multiply it in an endless succession of mirrors. It is capable of the highest and most variegated refinement, not only from within outwards, but also from without inwards; capable in that it organizes - for everything that seeks a wholeness in its effects - the parts along similar lines, so that it opens up a perspective upon an infinitely increasing classicism. Romantic poetry is in the arts what wit is in philosophy, and what society and sociability, friendship and love are in life. Other kinds of poetry are finished and are now capable of being fully analyzed. The romantic kind of poetry is still in the state of becoming; that, in fact, is its real essence: that it should forever be becoming and never be perfected. It can be exhausted by no theory and only a divinatory criticism would dare try to characterize its ideal. It alone 
Nessa passagem, que parece desenvolver a ideia kantiana de que a arte está associada ao "prazer desinteressado", Schlegel sublinha a qualidade de meio de reflexão do objeto artístico, assinalando a sua capacidade particular de multiplicar essa reflexão interminavelmente. Acrescenta Benjamin que, à semelhança do que sucede com o conhecimento dos objetos naturais, a observação da arte deve antes ser entendida como experiência, como uma atividade que a priori suspende as distinções entre sujeito e objecto: "criticism is, as it were, an experiment on the artwork, one through which the latter's own reflection is awakened, through which it is brought to consciousness and to knowledge of itself" (BENJAMIN, 2002, p. 151). É justamente este o sentido que podemos depreender de uma passagem seguinte no mesmo Fragmento 116, em que Schlegel escreve: "[a poesia romântica] can be exhausted by no theory and only a divinatory criticism would dare to try to characterize its ideal" (SCHLEGEL, 1991, p. 32). Nessa medida, será menos adequado dizer que se trata de refletir sobre a obra de arte do que dizer que se trata de refletir com a obra, e será justamente a maior ou menor capacidade que as obras de arte têm de produzir reflexão que estabelece a base para uma apreciação crítica.

Se a crítica partilha com o conhecimento da natureza a dimensão de suspensão das posições de sujeito e objeto, o conhecimento da arte envolve, contudo, a noção de "julgamento". Esta afirmação - paradoxal mediante o que foi já dito e aporética se tivermos em conta o quadro de pensamento sobre arte delineado pela filosofia de Emmanuel Kant, no qual se estabelecera a impossibilidade de aceitar critérios dogmáticos e universais para a apreciação artística - leva-nos a um dos mais importantes contributos da reflexão sobre crítica dos primeiros românticos. A saída para esse problema, como nota Benjamin, está em o crítico encontrar os critérios do seu exercício na própria obra: "Insofar as criticism is knowledge of the work of art, it is its self-knowledge; insofar as it judges the artwork, this occurs in the latter's self-judgment" (BENJAMIN, 2002, p. 151). ${ }^{4}$ A arte é, portanto, passiva de um julgamento, sendo, contudo, esse

is infinite, just as it alone is free; and it recognizes as its first commandment that the will of the poet can tolerate no law above itself. The romantic kind of poetry is the only one that is more than a kind, that is, as it were, poetry itself: for in a certain sense all poetry is or should be romantic." (SCHLEGEL, 1991, p. 31-32).

4 É esse o sentido prosseguido pela apresentação de Benjamin, que identifica três princípios básicos do julgamento artístico subjacentes à teoria do conhecimento da arte de 
julgamento apenas possível quando tem por base critérios imanentes à própria obra. Nesses termos, apenas pode haver crítica daquilo que possui uma reflexão a desvelar, daquilo que se pode absolutizar. $O$ julgamento não poderá ser exercido a partir de uma escala de valores dogmática, apenas se poderá afirmar, não sem dificuldade, se um trabalho é ou não arte. Importa aqui sublinhar, mesmo que brevemente, a dimensão absolutamente positiva da ação da crítica que decorre dessa visão. Pode-se falar numa vontade da parte dos primeiros românticos em superar o momento negativo de qualquer julgamento, associado à autodestruição da obra, em favor do momento positivo, indexado à intensificação da autocriação da obra por meio da crítica. É o que justamente encontramos expresso no Fragmento 29 dos Fragmentos Logológicos I, de Novalis: "He who cannot make poems will also be only able to judge them negatively. True criticism requires the ability to create the product to be criticized oneself. Taste alone only judges negatively" (NOVALIS, 1997, p. 55).

O termo utilizado por Schlegel para designar o modo como considera o empreendimento da crítica é "caracterização", menos associado ao estabelecimento de um juízo de valor que à compreensão do que Walter Benjamin designa por "ideal individual da obra" e está associado à remissão desse ideal individual à ideia de arte. Em Os pensamentos e opiniões de Lessing, reunidos e comentados a partir dos seus textos por Friedrich Schlegel (1804), Schlegel leva adiante o programa ambicioso de tornar explícito o espírito de Lessing segundo a sua máxima, exposta na própria Introdução Geral, de que: "A condição primeira de toda a compreensão, e por conseguinte também da compreensão de uma obra de arte, é a intuição do todo" (SCHLEGEL, 2015, p. 162). Para Schlegel, caracterizar é procurar a marca distintiva, seja de uma obra (Wilhelm Meister, por exemplo), de um conjunto de obras (Relato sobre as Obras Poéticas de Giovanni Boccaccio), de um autor (Lessing) ou mesmo de uma época (Poesia Grega e Romana). Trata-se de um gesto próximo ao da

Schlegel: "These three basic theses of the Romantic theory of the judgment of artworks can be formulated as the principle of the mediacy of judgment, the principle of the impossibility of a positive scale of values, and the principle of the uncriticizability of inferior work" (BENJAMIN, 2002, p. 159). Ressalve-se, como o faz o próprio Walter Benjamin, que esses princípios não se encontram explicitados de modo claro e distinto nos próprios textos dos primeiros românticos, nem constituíram um credo inapelável da sua prática; são antes elementos de um quadro que o próprio Benjamin organiza, tendo em conta os elementos filosóficos aos quais aqueles podem ser subsumidos. 
criação de um retrato e que, como dizia, pressupõe a existência de um ideal individual, elemento este que, por ideal, nos lança perante o desafio de compreender algo que está necessariamente num processo infinito de realização. O trabalho da crítica entendido como caracterização passa pela reflexão com a obra de arte, pela continuação da reflexão que esta revela imanente em si-mesma e, portanto, pela articulação dessa dimensão reflexiva e espiritual individual com o domínio do ideal absoluto da arte. Nas palavras de Benjamin:

Every critical understanding of an artistic entity is, as reflection in the entity, nothing other than a higher, self-actively originated degree of this entity's consciousness. Such intensification of consciousness in criticism is in principle infinite; criticism is therefore the medium in which the restriction of the individual work refers methodically to the infinitude of art and finally [endlich] is transformed into that infinitude [Unendlichkeit]. (BENJAMIN, 2002, p. 152)

Esse entendimento da atividade da crítica é fundamental para a própria compreensão da ideia de Romantismo sustentada pelos primeiros românticos, definida de modo particularmente pregnante por Novalis no Fragmento 66 dos Fragmentos Logológicos I nos seguintes termos:

To make Romantic is nothing but a qualitative raising to a higher power. [...] By endowing the commonplace with a higher meaning, the ordinary with mysterious respect, the known with the dignity of the unknown, the finite with the appearance of the infinite, I am making it Romantic. (NOVALIS, 1997, p. 60)

Importa sublinhar que esse movimento crítico, além do cunho da positividade, carrega consigo a marca da objetividade, porquanto se desenvolve a partir dos elementos constitutivos da obra, e é nesse sentido que Benjamin afirma:

Criticism is the preparation of the prosaic kernel in every work. In this, the concept "preparation" [Darstellung] is understood in the chemical sense, as the generation of a substance through a determinate process to which other substances are submitted. This is what Schlegel means when he says of Wilhelm Meister, "The work not only judges itself it also prepares itself". (BENJAMIN, 2002, p. 178) 
Segundo Constantino de Medeiros, Schlegel sustenta, nos seus Fragmentos sobre a Poesia e Literatura, que a caracterização busca determinar a essência, o ideal individual da obra, através de um estudo dos elementos espirituais (tendência, tom e maneira) e dos elementos materiais (forma, matéria e estilo) nela presentes (DE MEDEIROS, 2015, p. 190). ${ }^{5}$ Nessa medida, ainda que haja uma dimensão necessariamente especulativa na determinação do elemento ideal da obra, a crítica não deve deixar de se pautar por uma inclinação analítica. Esse parece ser o sentido do Fragmento 57, em que Schlegel escreve:

If some mystical art lovers who think of every criticism as a dissection and every dissection as a destruction of pleasure were to think logically, then "wow" would be the best criticism of the greatest work of art. To be sure, there are critiques which say nothing more, but only take much longer to say it. (SCHLEGEL, 1991, p. 7)

Estamos perante a busca de um procedimento em que o escrutínio de uma obra ambiciona não perder nem a dimensão poética nem a dimensão rigorosa.

Na medida em que o conhecimento se dá por uma experiência, por um processo de observação mágica, associado a uma dimensão divinatória necessária ao estabelecimento do ideal individual da obra, Benjamin aproxima a crítica daquilo que Novalis designou por "tradução mítica": "They [tradutores míticos] represent the pure, perfected character of the individual work of art. They do not give us the real work of art but the ideal of it. [...] A mind is needed where the spirit of poetry and the spirit of philosophy have saturated each other in all their fullness" (NOVALIS, 1997, p. 33-34). ${ }^{6}$ Descobrindo

5 Constantino de Medeiros utiliza a noção de diaskenase para explicitar o sentido do trabaIho crítico, tal como terá sido entendido por Schlegel. O termo grego a que de Medeiros faz referência e que terá sido utilizado pelo próprio Schlegel em Geschichte der Poesie der Griechen und Römer [História da Poesia dos Gregos e Romanos] (1796) abrange um campo semântico que compreende: "construir, organizar, pôr em ordem, disfarçar com vestes, preparar uma pessoa para a ação ou a guerra, revestir com ornamentos ou apetrechos, manipular medicamentos", designando, contudo, em sentido restrito, a actividade dos críticos de Alexandria implicados no entendimento histórico e sistemático dos textos homéricos (DE MEDEIROS, 2015, p. 104). Essa escolha parece reforçar o termo "preparação", selecionado por Walter Benjamin, sublinhando assim a dimensão de rigor da exegese crítica.

6 O fragmento 68 merece a transcrição integral: "A translation is either grammatical, or modi- 
as tendências secretas de uma obra e contribuindo para a realização das suas intenções ocultas, a crítica constitui-se como uma continuação da obra, como um novo momento da sua metamorfose. Em concordância com essas passagens, poder-se-á acrescentar as afirmações de Schlegel sobre a crítica enquanto caracterização: "não é possível dizer que se compreende uma obra, um espírito, senão quando se é capaz de reconstruir o seu percurso e a sua estrutura" (SCHLEGEL, 2015, p. 170). Para conseguir realizar esse movimento, Schlegel exige do crítico um comportamento particular que expõe a individualidade da obra "de modo mímico", comportando-se como "ele mesmo e, ao mesmo tempo, outra pessoa" (SCHLEGEL apud DE MEDEIROS, 2015, p. 191-192). Essa linha de pensamento é afim à posição mantida por Novalis, por exemplo, quando escreve: "Só mostro que compreendi um escritor quando puder atuar dentro do seu espírito, quando o conseguir traduzir e alterar de diversas maneiras, sem reduzir a sua individualidade" (NOVALIS, 2000, p. 31). Continua de Medeiros afirmando que a crítica, para Schlegel, constitui-se como uma tarefa de contemplação e acabamento da obra, um reestabelecimento do texto e de reconstrução do sentido da obra. Aproximando-se a crítica, então, de um "pensar sobre o pensar", de uma "reflexão sem limites", podemos dizer que a tarefa infinita da crítica a torna uma espécie de "criação de segunda potência", na qual o crítico se associa ao interminável metamorfosear-se da obra.

Salientei alguns aspectos da concepção de crítica de Friedrich Schlegel, seguindo a exposição levada adiante por Walter Benjamin e Constantino de Medeiros. Não é de menos voltar a assinalar o quanto a noção de crítica

\footnotetext{
fying, or mythical. Mythical translations are translations of the highest kind. They represent the pure, perfected character of the individual work of art. They do not give us the real work of art but the ideal of it. There still does not exist, I believe, complete example of such a translation. But in the spirit of many a critique and description of works of art clear signs are to be found. A mind is needed where the spirit of poetry and the spirit of philosophy have saturated each other in all their fullness. Greek mythology is in part such a translation of a national religion. The modern Madonna too is such a myth. Grammatical translations are translations in the usual sense. They require a great deal of learning - but only discursive abilities. Modifying translations, if they are to be genuine, demand the highest poetic spirit. They easily slip into travesty-like Burger's Homer in iambics - Pope's Homer - all French translations. The true translator of this kind must indeed be an artist himself and be able to produce the idea of the whole at will in one way or another. He must be the poet of the poet and thus be able to let him speak according to his own and the poet's idea at the same time. The genius of humanity stands in a similar relation to each single person. Not only books but everything can be translated in these three ways." (NOVALIS, 1997, p. 33-34).
} 
para Schlegel, mas também para toda uma geração posterior a Kant, assume um caráter objetivamente produtivo. Como nota Benjamin: "the term explicitly connoted not the sense of a merely discerning, unproductive state of mind; rather, for the Romantics and for speculative philosophy, the term 'critical' meant objectively productive, creative out of thoughtful deliberation" (BENJAMIN, 2002, p. 42). Apenas nessa perspectiva se poderá entender o significado da afirmação de Benjamin de que, para os primeiros românticos, a crítica é o conhecimento no meio de reflexão que é a arte, bem como as noções de caracterização e de criação em segunda potência propostas por Schlegel.

\section{Crítica e produção de subjetividade}

Na secção anterior procurei apresentar alguns dos aspectos da noção de crítica de arte proposta por Friedrich Schlegel e pelos primeiros românticos, fazendo alusão a quanto para esses autores se aproximavam as ideias de arte e de crítica. No âmbito deste texto é importante salientar ainda o quanto essa visão estética se imbrica num entendimento particular do papel político da arte e do artista. Esse movimento permitir-me-á estabelecer um nexo entre o pensamento que temos vindo a analisar e a problemática da produção de subjetividade.

No fragmento 116 da Revista Athenaeum, Schlegel escreve, a propósito da poesia romântica, que ela não apenas procura fundir inspiração e criticismo, como também procura desempenhar um papel no plano social, na medida em que busca tornar a literatura viva e sociável do mesmo modo que visa tornar a vida e a sociedade poéticas (SCHLEGEL, 1991, p. 31-32). Essa reciprocidade entre a poética e a política surge também expressa no Fragmento Crítico 65, em que Schlegel descreve a literatura enquanto um território cujas leis são análogas às da sociedade ideal e cujos limites enformam de modo idêntico o vir a ser dos humanos: "Poetry is republican speech: a speech which is its own law and end unto itself, and in which all the parts are free citizens and have the right to vote" (SCHLEGEL, 1991, p. 8). Constantino de Medeiros observa que, se é verdade que muitos heróis da literatura e da arte dos primeiros românticos realizam percursos individuais de desenvolvimento e transformação pessoal, não se pode deixar de observar que tem isto habitualmente lugar 
como modo de valorizar o despertar da intuição e a expansão da imaginação enquanto faculdades necessárias aos homens para criar uma sociabilidade fraterna (DE MEDEIROS, 2015, p. 101). Mas Schlegel e os primeiros românticos não apenas pretenderam que a poesia romântica, enquanto poesia da poesia, constituísse um vector de aperfeiçoamento e promoção de uma nova sociabilidade, de certo modo ecoando as ideias de Friedrich von Schiller sobre A Educação Estética do Homem (1793), como também se lançaram eles próprios em práticas de produção e em modos de vida que colocavam em acção essa visão artística da existência.

É no quadro do pensamento estético de Schlegel, Novalis e outros primeiros românticos que as noções de "simpoesia" e "sinfilosofia" têm lugar, noções estas que permitem um trânsito singular entre os domínios da literatura e da política e que nos colocam no âmago de uma visão do artista relevante para a discussão contemporânea da subjetividade. Com efeito, escreve Schlegel no Fragmento Crítico 112: "[o escritor romântico] doesn't try to make any particular impression on him [o leitor], but enters with him into the sacred relationship of deepest symphilosophy or sympoetry" (SCHLEGEL, 1991, p. 14). ${ }^{7}$ No domínio da crítica de arte, já o vimos anteriormente, essas ideias articulam-se com o que assinalei a propósito da caracterização, tal como a entendeu Schlegel, e com a noção de "tradução mítica" e o que foi destacado do pensamento de Novalis, no final da secção anterior. Mas aqui estamos perante um entendimento da relação entre a obra de arte e os seus receptores marcada por uma sociabilidade não totalitária e a propósito da qual seria muito pertinente evocar a noção de abertura, tal como a propôs Umberto Eco (1962/1976). Mas é pertinente notar também, como faz Allen Speight (2015), que essa perspectiva estética está no centro de uma atividade propriamente política, na medida em que a meta de uma sociabilidade livre e dialógica constituiu a prática existencial dos primeiros românticos nos seus salões e nos seus projetos artísticos cooperativos, com destaque para

7 112. "The analytic writer observes the reader as he is; and accordingly he makes his calculations and sets up his machines in order to make the proper impression on him. The synthetic writer constructs and creates a reader as he should be; he doesn't imagine him calm and dead, but alive and critical. He allows whatever he has created to take shape gradually before the reader's eyes, or else he tempts him to discover it himself. He doesn't try to make any particular impression on him, but enters with him into the sacred relationship of deepest symphilosophy or sympoetry" (SCHLEGEL, 1991, p. 14). 
o trabalho desenvolvido na Revista Athenaeum. Com efeito, é justamente nessa revista que reencontramos as noções de "simpoesia" e sinfilosofia", nomeadamente no Fragmento 125, no qual Schlegel escreve: "Perhaps there would be a birth of a whole new era of the sciences and arts if symphilosophy and sympoetry became so universal and heartfelt that it would no longer be anything extraordinary for several complementary minds to create communal works of art" (SCHLEGEL, 1991, p. 34). ${ }^{8}$ Nessa medida, a visão de Schlegel e dos primeiros românticos sobre a produção crítica articula-se com um entendimento do mundo que combina a absoluta liberalidade dos indivíduos com a possibilidade da completa partilha e colaboração entre eles. Se aceitarmos o diagnóstico de Giorgio Agamben de que vivemos hoje um tempo saturado de processos massificados de subjetivação e de acelerada dessubjetivação (AGAMBEN, 2009, p. 48), talvez as noções de crítica e de simpoesia trabalhadas pelo jovem Friedrich Schlegel e pelos primeiros românticos possam contribuir para criar gestos de resistência, formas de permanecer no umbral das identidades normativas e normalizadas, formas de corpo a corpo produtivas e fraternas por meio de ausências singulares.

\section{Referências bibliográficas}

AGAMBEN, G. O que é o contemporâneo? e outros ensaios. Chapecó: Argos, 2009.

BENJAMIN, W. The concept of art criticism in German Romanticism. In: BENJAMIN, W. Selected writings. Cambridge; London: The Belknap Press of Harvard University Press, 2002. v. 1, p. 116-200.

DE MEDEIROS, C. L. A crítica literária de Friedrich Schlegel. 2015. 405 f. Tese (Doutorado em Teoria Literária e Literatura Comparada) - Faculdade de Filosofia, Letras e Ciências Humanas, Universidade de São Paulo, São Paulo, 2015

8 125. "Perhaps there would be a birth of a whole new era of the sciences and arts if symphilosophy and sympoetry became so universal and heartfelt that it would no longer be anything extraordinary for several complementary minds to create communal works of art. One is often struck by the idea that two minds really belong together, like divided halves that can realize their full potential only when joined. If there were an art of amalgamating individuals, or if a wishful criticism could do more than merely wish - and for that there are reasons enough - then I would like to see Jean Paul and Peter Leberechtf combined. The latter has precisely what the former lacks. Jean Paul's grotesque talent and Peter Leberecht's fantastic turn of mind would, once united, yield a first rate romantic poet" (SCHLEGEL, 1991, p. 34). 
NOVALIS. Fragmentos. Lisboa: Assírio \& Alvim, 2000.

NOVALIS. Philosophical writings. New York: State University of New York Press, 1997.

SCHLEGEL, F. Da essência da crítica e outros textos. Lisboa: Fundação Calouste Gulbenkian, 2015.

SCHLEGEL, F. Philosophical fragments. Minneapolis: University of Minnesota Press, 1991.

SPEIGHT, A. Friedrich Schlegel. In: ZALTA, E. N. (Ed.). The Stanford Encyclopedia of Philosophy. Stanford: Stanford University, 2015. Disponível em: <http://plato. stanford.edu/archives/win2015/entries/schlegel/>. Acesso em: 4 set. 2016.

Recebido em 30/09/2016 Aprovado em 31/10/2016

Publicado em 21/12/2016 